Jap. J. M. Sc. \& Biol., 10, 343-361, 1957

\title{
STUDIES ON THE RELATIONSHIP BETWEEN TOXIN ANAPHYLAXIS AND ANTITOXIC IMMUNITY \\ III. SIGNIFICANCE OF ALLERGIC REACTION ON THE NEUTRALIZA- TION OF TOXIN INJECTED INTRACUTANEOUSLY
}

\author{
KIMISHIge ISHIZAKA ${ }^{1)}$, TERUKo ISHIZAKA ${ }^{2}$, TAKAO SUGAHARA ${ }^{3 \text { ) }}$ \\ AND SHIZUE MARUYAMA4) \\ Department of Serology, National Institute of Health, Tokyo5)
}

(Received: August 26th, 1957)

It has hitherto been believed that the antitoxic immunity is established by the circulating antitoxin and that the allergy is caused by antigen antibody reaction in the tissues. However, there are some findings which can not be explained by this thesis. For example, as reported by Kurokawa et al. (1951), the neutralizing capacity of the immunized guinea pigs to the toxin injected intracutaneously could not be explained by the circulating antitoxin alone. Moreover, the ratio of the tissue antitoxin concentration to the circulating antitoxin concentration is different depending on the period after immunization and the neutralization index parallels with the ratio of tissue antitoxin/circulating antitoxin (Ishizaka et al., 1955). This finding implies that tissue antitoxin plays an important role in Schick reaction. But, the dosis of antitoxin extracted from the skin of immunized guinea pigs was relatively little as compared with the neutralizing activity of the guinea pigs to the toxin injected intracutaneously. Therefore, it is doubtful that the toxin injected intracutaneously is neutralized with the tissue antitoxin alone.

In the present study, homologous and heterologous antitoxins were used for passive immunization and the relation between the degree of immunity, determined by Schick test and the concentration of tissue-antitoxin was studied. As the results, the significance of allergic reaction on the neutralization of toxin in the tissues was clarified.

\section{MATERIALS AND Methods}

The antitoxins used for passive immunization of guinea pigs were as follows: 1. guinea pig antitoxic serum obtained from guinea pigs hyperimmunized with alum precipitated toxoid $(65$ units/cc) ; 2. rabbit antitoxic serum obtained from rabbits hyperimmunized with the same toxoid $(40$ units/cc); 3. equine antitoxic serum $(1100$

1）石坂公成・2）石坂照子・3）菅原孝雄・4）丸山静枝，5）国立予防衛生研究所血清部 
units/cc); 4. equine antitoxin purified by Pope's method (5500 units/cc), which was obtained by the courtesy of Dr. T. Katsura of the Institute for Infectious Diseases; 5. rabbit's antitoxin digested ( 40 units/cc), which was prepared by Pope's method (1939) in our laboratory (Ishizaka, 1955). These antitoxins were titrated by Jensen's method (1933) and flocculation or precipitation. The units of each antitoxin determined by both methods were just similar with each other. Passive immunization of guinea pigs was carried out by the intravenous injection of these antitoxins.

For the determination of the circulating antitoxin titer and the titer of tissue antitoxin extracted, Jensen's method (1933) was used. One M.R.D., 20 $\times$ LR/200, $20 \times \mathrm{LR} / 2000,20 \times \mathrm{LR} / 20000$ of the test toxin were $0.00005 \mathrm{cc}, 0.033 \mathrm{cc}, 0.0033 \mathrm{cc}$, and $0.00033 \mathrm{cc}$ respectively. The concentration of the tissue antitoxin and the circulating antitoxin was determined taking avidity of antitoxin into consideration (Jerne, 1951).

In order to determine the intensity of immunity, Quantitative Schick Test (Q.S.T.) was applied. Namely, serial dilutions of toxin, $0.1 \mathrm{cc}$ of each, were injected intracutaneously to guinea pigs previously depilated in their back. The toxin used was the same as the test toxin for the antitoxin titration. The reading was made 40 to 48 hours after the injection of the test toxin. The minimum dosis of toxin in terms of $L R$, required to cause positive reaction beyond distinct redness of 9 to $10 \mathrm{~mm}$ in diameter was taken as the titer of Q.S.T. of each animal. The titer of Q.S.T. was divided by the circulating antitoxin titer. This figure, which is called the neutralization. index (N.I) by Kurokawa et al. (1951), represents the ratio of neutralizing power to the toxin injected intracutaneously to the circulating antitoxin titer.

Extraction of antitoxin: Twenty four hours after the intravenous injection of an adequate dosis of antitoxin, the skin of the guinea pigs was taken out after bleeding and it was minced drastically in the mortor. After the addition of saline solution, it was homogenized by Waring blender and Potter type glass-homogenizer. The homogenate obtained was frozen in a dry ice-acetone mixture and was kept frozen for 10 minutes before thawing in a $37^{\circ} \mathrm{C}$ water bath for a total of 3 cycles. The suspension was centrifuged for 10 minutes at $10,000 \mathrm{~g}$ and the antitoxin titer of the supernatant fluid was determined.

Preparation of radioiodinated serum globulin: Fractionation of guinea pig serum and rabbit serum was performed according to Nichol et al. (1948) and crude $\gamma$ globulin fraction was obtained. Equine antitoxic serum was fractionated following Deutsch et al. (1948) and ppt A was obtained. Iodination of serum $\gamma$-globulin was performed according to the technic of Cohen (1951) with slight modification. Namely, carrier free $I^{131}(0.66-1.0 \mathrm{mc})$ was added to the approximate amount of solution of $0.09 \mathrm{~N}$ iodine in $0.1 \mathrm{~N}$ potassium iodide. After equilibration for 30 minutes in an ice-water bath, a chilled $\gamma$-globulin solution which had been dialyzed for 24 hours against borate buffer ( $\mathrm{pH}$ 8.9) was added and the whole was kept in ice water for 1 hour. Then it was dialyzed against repeated changes of phosphate buffer saline ( $\mathrm{pH} \mathrm{7.0)}$ in the cold for 48 hours. Iodine combined was equivalent to an average of 0.3 to 0.8 atoms per globulin molecule.

Preparation of samples for measurement of radioactivity: Samples were prepared following the method of Pressman et al. (1948). The skin to be measured for radioactivity was macerated in distilled water and to this was added $0.5 \mathrm{cc}$ of $0.1 \mathrm{~N}$ potassium iodide solution as carrier, $1.5 \mathrm{cc}$ of $1 \mathrm{~N}$ silver nitrate solution, $5 \mathrm{cc}$ of concentrated nitric acid and $2.5 \mathrm{cc}$ of $30 \% \mathrm{H}_{2} \mathrm{O}_{2}$. The flask was heated in a water bath at $80^{\circ} \mathrm{C}$ for 1 hour. After cooling, the digest was centrifuged. The silver halide precipitate was washed with alcohol, ether and finally with acetone and spread to a uniform thickness on aluminium holder and dried under a lump.

In order to avoid the significant self-absorption error and geometric error, $0.1 \mathrm{cc}$ 
of serum of which radioactivity was to be compared with that of skin was added to $0.5 \mathrm{cc}$ of $0.1 \mathrm{~N}$ potassium iodide and $0.1 \mathrm{cc}$ of $1 \mathrm{~N}$ silver nitrate and the whole was spread on aluminium holder. These samples contained a mixture of silver chloride and silver iodide of the same thickness. The measurement of radioactivity was made with a Geiger Müller counter. Corrections were made for back ground count, decay and when necessary, coincidence error.

Radioactivity of skin was compared with that of $\mathrm{I}^{131}$-labeled $\gamma$-globulin fraction used for passive immunization. The concentration of tissue antitoxin was calculated from the radioactivity. By the way, when $\mathrm{I}^{131}$-labeled antitoxin was injected to actively immunized guinea pigs, the circulating antitoxin titer and the radioactivity of the skin and serum were determined 24 hours after passive immunization. The concentration of the tissue antitoxin was calculated supposing that the ratio of the antitoxin titer to the radioactivity of the serum is in accordance with the ratio of the tissues.

\section{EXPERIMENTAL RESULTS}

1. Comparison of Immunizing Activity of Various Antitoxin Determined by Quantitative Schick Test.

Firstly, guinea pigs were passively immunized with 24 to 48 units of guinea pig antitoxin or equine antitoxin and the titer of Q.S.T. was pursued. The results are shown in Table 1 . When the guinea pig antitoxin was used, the

Table 1. Quantitative Schick Test of passively immunized guinea pigs

\begin{tabular}{|c|c|c|c|c|c|c|}
\hline $\begin{array}{c}\text { Antitoxin } \\
\text { injected }\end{array}$ & $\begin{array}{c}\text { Number of } \\
\text { guinea pigs }\end{array}$ & $\begin{array}{c}\text { Incubation } \\
\text { period }\end{array}$ & $\begin{array}{l}\text { Circulating } \\
\text { antitoxin }\end{array}$ & $\begin{array}{l}\text { Titer of } \\
\text { Q.S.T. }\end{array}$ & Neutralization & $\begin{array}{l}\text { Index } \\
\text { mean } \\
\end{array}$ \\
\hline \multicolumn{7}{|c|}{ A) Guinea pig antitoxin } \\
\hline$\underset{32}{\text { units }}$ & 4 & $\underset{1}{\operatorname{hours}}$ & $\underset{1.0-1.5}{\operatorname{units} / \mathrm{cc}}$ & $\begin{array}{r}\mathrm{LR} \\
0.0125\end{array}$ & $0.008-0.012$ & 0.01 \\
\hline $25-32$ & 5 & 24 & $0.65-1.0$ & $0.1-0.2$ & $0.1-0.19$ & 0.135 \\
\hline $25-32$ & 5 & 48 & $0.4-0.5$ & $0.05-0.1$ & $0.094-0.24$ & 0.174 \\
\hline $25-32$ & 6 & 96 & $0.33-0.8$ & $0.05-0.1$ & $0.15-0.3$ & 0.176 \\
\hline \multicolumn{7}{|c|}{ B) Equine antitoxin } \\
\hline 24 & 3 & 1 & $1.2-1.3$ & 0.0125 & $0.0096-0.0104$ & 0.01 \\
\hline 36 & 5 & 24 & $0.65-0.9$ & $0.0125-0.025$ & $0.016-0.032$ & 0.025 \\
\hline 36 & 5 & 48 & $0.33-0.45$ & 0.025 & $0.046--0.066$ & 0.052 \\
\hline $36-48$ & 7 & 96 & $0.25-0.4$ & $0.00625-0.0125$ & $0.017-0.042$ & 0.037 \\
\hline
\end{tabular}

titer of Q.S.T., 1 hour after immunization, was $0.0125 \mathrm{Lf}$, though the circulating antitoxin titer was 1 to 1.5 units/cc. While, 24 hours after immunization, titer of Q.S.T. increased to 0.1 to $0.2 \mathrm{LR}$ in spite of the decreased circulating antitoxin titer. In other words, the neutralization index increased rapidly in 24 hours by 13 times. (Table 1A). Such finding implies that the tissue antitoxin plays an important role in the neutralization of toxin injected intracutaneously. On the other hand, when equine antitoxin was used for passive immunization, the titer of Q.S.T., 1 hour after immunization, was comparable with the titer in the guinea 
pigs immunized with guinea pig antitoxin. In those guinea pigs, however, the titer of Q.S.T. did not increase after 24 hours and the increase of the neutralization index was only about 2.5 times (Table $1 \mathrm{~B}$ ).

Secondly, guinea pigs were immunized with 4 kinds of antitoxin and Q.S.T. was carried out 24 hours later. The results were shown in Table 2. From this

Table 2. Properties of antitoxin used and Quantitative Schick Test

\begin{tabular}{|c|c|c|c|c|c|c|c|}
\hline \multicolumn{2}{|l|}{ Antiserum } & \multirow{2}{*}{$\begin{array}{c}\text { Number of } \\
\text { guinea } \\
\text { pigs }\end{array}$} & \multirow{2}{*}{$\begin{array}{c}\text { Incuba- } \\
\text { tion } \\
\text { time }\end{array}$} & \multirow{2}{*}{$\begin{array}{l}\text { Circulat- } \\
\text { ing } \\
\text { antitoxin }\end{array}$} & \multirow{2}{*}{$\begin{array}{l}\text { Titer } \\
\text { of } \\
\text { Q.S.T. }\end{array}$} & \multirow{2}{*}{\multicolumn{2}{|c|}{$\frac{\text { Neutralization Index }}{\text { mean }}$}} \\
\hline species & $\begin{array}{c}\text { dosis } \\
\text { injected }\end{array}$ & & & & & & \\
\hline Guinea pig & $\begin{array}{l}\text { units } \\
25-32\end{array}$ & 5 & $\underset{24}{\operatorname{hours}}$ & $\begin{array}{l}\text { units/cc } \\
0.65-1.0\end{array}$ & $\frac{L R}{0.1-0.15}$ & $0.1-0.15$ & 0.135 \\
\hline Rabbit & 32 & 5 & 24 & $0.9-1.3$ & $0.1-0.2$ & $0.09-0.15$ & 0.12 \\
\hline Horse & 36 & 5 & 24 & $0.65-0.9$ & $0.0125-0.025$ & $0.016-0.032$ & 0.025 \\
\hline Horse digested & 50 & 4 & 24 & $1.2-1.3$ & 0.025 & $0.019-0.021$ & 0.0205 \\
\hline Rabbit digested & 40 & 4 & 24 & $0.03-0.05$ & $0.0033-0.0065$ & $0.08-0.16$ & 0.118 \\
\hline
\end{tabular}

table it is clear that the neutralization index is high when guinea pigs were immunized with guinea pig antitoxin or rabbit antitoxin and that the neutralization index is low when either the equine antitoxin or equine antitoxin digested was used. As for the rabbit antitoxin digested, the titer of Q.S.T. was low in spite of high neutralization index. The reason of which would be the rapid disappearance rate of the antitoxin from the circulation as will be described below. At any rate, the tolerance of guinea pigs to the toxin injected intracutaneously is different depending not only on the dosis of antitoxin used for immunization but also on its property.

\section{Sensitizing Activity of Various Antitoxin.}

As reported previously, the toxin anaphylaxis in vitro was observed in the guinea pigs immunized passively with guinea pig antitoxic serum (Ishizaka et al., 1953) or rabbit antitoxic serum (Ishizaka, 1955). On the contrary, either equine antitoxic serum or equine antitoxin digested has no sensitizing activity. The sensitizing activity of rabbit antitoxin digested was very weak as compared with rabbit antitoxic serum (Ishizaka, 1955). In the present experiment, the sensitizing activities of these antitoxins were compared with each other in the allergic skin-reaction. Guinea pigs were sensitized with adequate dosage of these antitoxins and 24 hours later, $0.1 \mathrm{cc}$ of purified toxoid, variously diluted, was injected intracutaneously on one side of their back. At the same time, Q.S.T. was carried out on the other side of their back. The circulating antitoxin titer was also determined. The results obtained were shown in Table 3. Namely, skin reaction was positive when guinea pig antitoxin or rabbit antitoxin was used. But it was negative when equine antitoxic serum or purified equine antitoxin was used though the titer of Q.S.T. were comparable in these cases. In other words, the intensity of toxin antitoxin reaction in the skin seemed to be comparable in these cases. The allergic reaction was observed in 
every cases, excepting a case the equine antitoxin reacted with toxoid.

Such difference of sensitizing activity depending on the property of antitoxin was also observed in Prausnitz-Küstner's reaction. Guinea pigs were given intracutaneous injections each of $0.1 \mathrm{cc}$ of antitoxin. After 30 minutes to 24 hours, 0.1 cc of purified toxoid was injected into the sites prepared for this

Table 3. Arthus reaction and Quantitative Schick Test

\begin{tabular}{|c|c|c|c|c|c|c|c|c|c|c|}
\hline \multirow{2}{*}{ No } & \multirow{2}{*}{$\begin{array}{l}\text { Body } \\
\text { weight }\end{array}$} & \multicolumn{2}{|c|}{ Antitoxin } & \multirow{2}{*}{$\begin{array}{l}\text { Circulating } \\
\text { antitoxin }\end{array}$} & \multirow[b]{2}{*}{$\overline{16 \mathrm{Lf}^{* *}}$} & \multirow{2}{*}{$\begin{array}{l}\text { Arthus } \\
\text { 8Lf }\end{array}$} & \multicolumn{2}{|c|}{ reaction* } & \multirow{2}{*}{$\begin{array}{l}\text { Titer of } \\
\text { Q.S.T. }\end{array}$} & \multirow{2}{*}{ N.I. } \\
\hline & & species & dosis & & & & & intensity & & \\
\hline & $\mathrm{g}$ & & units & $\mathrm{u} / \mathrm{cc}$ & & & & & LR & \\
\hline 1 & 375 & guinea pig & 32 & 1.0 & $20 \times 17$ & $15 \times 15$ & $13 \times 12$ & $2+$ & 0.1 & 0.1 \\
\hline 2 & 350 & guinea pig & 32 & 0.8 & $10 \times 10$ & $7 \times 7$ & $5 \times 5$ & + & 0.1 & 0.125 \\
\hline 3 & 300 & guinea pig & 50 & 2.0 & $10 \times 13$ & $10 \times 10$ & $7 \times 8$ & + & 0.2 & 0.1 \\
\hline 4 & 410 & horse & 165 & 9.0 & $7 \times 4$ & - & - & - & 0.2 & 0.022 \\
\hline 5 & 410 & rabbit & 38 & 1.0 & $12 \times 11$ & $8 \times 6$ & \pm & + & 0.1 & 0.1 \\
\hline 6 & 360 & rabbit digested & 40 & 0.07 & $7 \times 3$ & - & - & - & 0.0065 & 0.09 \\
\hline 7 & 400 & horse digested & 150 & 2.5 & $8 \times 8$ & \pm & - & - & 0.1 & 0.04 \\
\hline
\end{tabular}

purpose. Allergic reaction was observed only in the guinea pigs sensitized with guinea pig antitoxin or rabbit antitoxin (Table 4). Moreover, corresponding results were observed when these antitoxin was injected after the injection of toxoid. The results obtained with the rabbit antitoxin digested was a little different. In this case, positive reaction was observed when the toxoid was injected 30 minutes after antitoxin injection. While, the reaction was negative, when the toxoid was injected 18 hours after antitoxin injection. Similar results were reported by Kuhns and Pappenheimer (1952) using non-sensitizing human diphtheria antitoxin. It seems that the rapid disappearing rate of rabbit antitoxin digested would have some connection with the results.

In short, both the immunizing activity and the sensitizing activity of antitoxin are different depending on the property of antitoxin used. Moreover, the neutralization index is generally high when the antitoxin having sensitizing activity is used for immunization.

3. Disappearance Rate of Antitoxin from the Circulation and the Concentration of Tissue Antitoxin.

As described above, the tissue antitoxin seems to play an important role in the neutralization of toxin injected intracutaneously. Moreover, the neutralizing activity of the toxin injected intracutaneously was different depending on the property of antitoxin used for immunization. In this connection, it was examined that whether or not the disappearance rate of antitoxins from the circulation as well as the concentration of tissue antitoxin 24 hours after immunization are divergent depending on the property of antitoxin used for immunization. The disappearance rate of antitoxin following intravenous injection of various anti- 


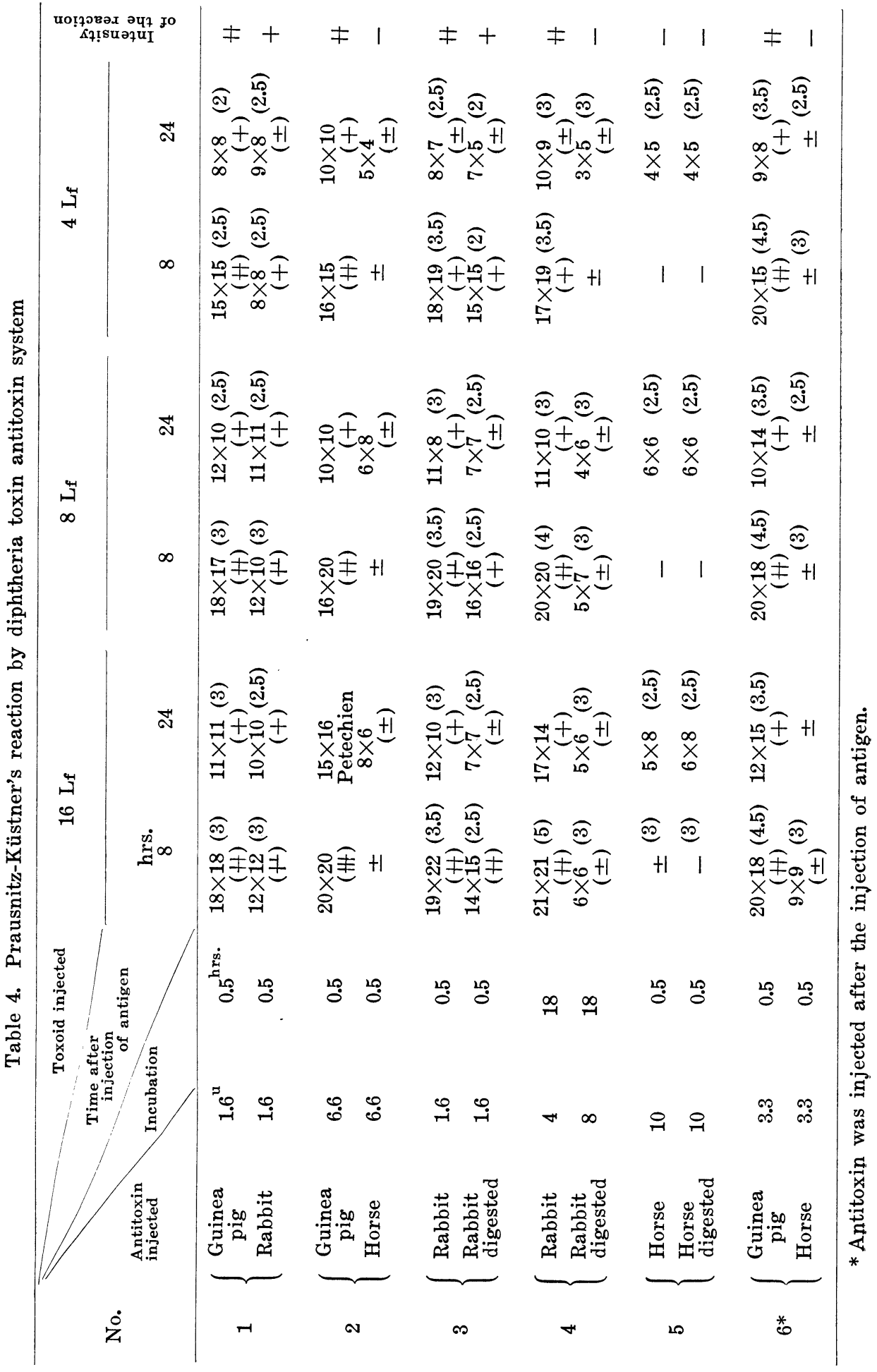


toxins were determined as follows; Guinea pig antitoxin (31 units), rabbit antitoxin (32 units), equine antitoxin (30 units), equine antitoxin digested (50 units) and rabbit antitoxin digested (40 units) were injected intravenously to guinea pigs and the concentration of the circulating antitoxin was determined at varying intervals from 1 hour to 96 hours after injection. The disappearance rate of $\mathrm{I}^{131}$-labeled $\gamma$-globulin was also determined. Specific activity of these guinea pig serum immediately after the injection of radioactive $\gamma$-globulin was determined and the serum volume of the guinea pig was estimated to be $1 / 20$ of their body weight. The concentration of antitoxin as well as $\mathrm{I}^{131}$-labeled $\gamma$ globulin immediately after the injection was calculated and it was assumed to be $100 \%$. Fig. 1, which is a semilogarithmic plot of antitoxin content of serum

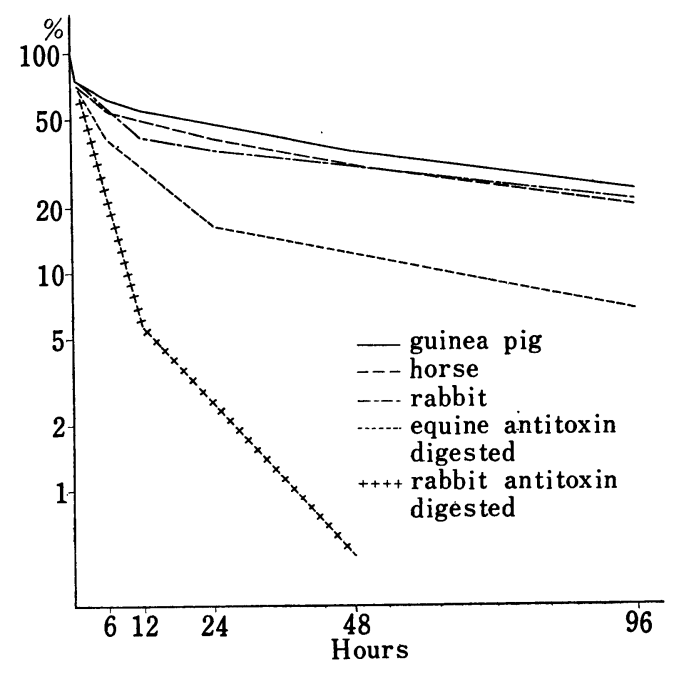

Fig. 1. Disappearance rate of antitoxin from the circulation.

against time, shows that the disappearance rate of guinea pig, rabbit and equine antitoxin are comparable with each other. While the disappearance rate of equine antitoxin digested was a little earlier than the native one and the elimination of rabbit antitoxin digested was very rapid. The rate of the disappearance of $\mathrm{I}^{131}$-labeled gamma globulin agrees almost exactly with that of passively administered antitoxin (Fig. 2). These findings are in accordance with the results obtained by Talmage et.al. (1951).

In the next place, these antitoxins were used for immunization and 24 hours later, tissue antitoxin was extracted from the skin. As shown in Table 5, the ratio of the tissue antitoxin to the circulating antitoxin was the same being independent on the properties of antitoxin used. Moreover, the concentration of tissue antitoxin was only 2 to $4 \%$ of the circulating antitoxin concentration. In other words, the concentration of tissue antitoxin was too low as compared 


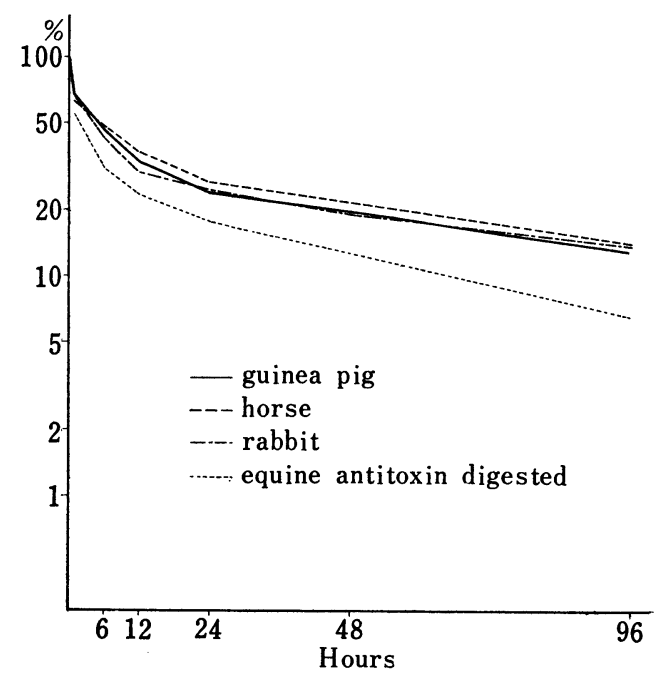

Fig. 2. Disappearance rate of $\mathrm{I}^{131}$-labeled $\gamma$-globulin from the circulation

Table 5. Concentration of antitoxin in the skin

\begin{tabular}{|c|c|c|c|c|c|c|}
\hline No. & Antitoxin & $\begin{array}{c}\text { Body- } \\
\text { weight }\end{array}$ & $\begin{array}{c}\text { Dosis of } \\
\text { injection }\end{array}$ & $\begin{array}{l}\text { Antitoxin } \\
\text { concentration } \\
\text { in the skin }\end{array}$ & $\begin{array}{c}\text { Circulating } \\
\text { antitoxin } \\
\text { concentration }\end{array}$ & 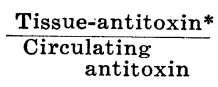 \\
\hline & & $\mathrm{g}$ & $\mathrm{u}$ & $\mathrm{u} / \mathrm{g}$ & $\mathrm{u} / \mathrm{cc}$ & $\%$ \\
\hline $\begin{array}{l}1 \\
2\end{array}$ & Guinea pig & $\begin{array}{l}330 \\
340\end{array}$ & $\begin{array}{l}144 \\
100\end{array}$ & $\begin{array}{l}0.11 \\
0.047\end{array}$ & $\begin{array}{l}4.0 \\
2.5\end{array}$ & $\begin{array}{l}3.0 \\
2.3\end{array}$ \\
\hline $\begin{array}{l}3 \\
4\end{array}$ & Rabbit & $\begin{array}{l}280 \\
250\end{array}$ & $\begin{array}{l}40 \\
40\end{array}$ & $\begin{array}{l}0.058 \\
0.045\end{array}$ & $\begin{array}{l}2.0 \\
2.0\end{array}$ & $\begin{array}{l}3.2 \\
2.0\end{array}$ \\
\hline $\begin{array}{l}5 \\
6 \\
7\end{array}$ & Equine & $\begin{array}{l}320 \\
295 \\
285\end{array}$ & $\begin{array}{r}330 \\
550 \\
1100\end{array}$ & $\begin{array}{l}0.511 \\
0.54 \\
1.08\end{array}$ & $\begin{array}{l}20.0 \\
20.0 \\
40.0\end{array}$ & $\begin{array}{l}2.8 \\
3.0 \\
3.0\end{array}$ \\
\hline $\begin{array}{l}8 \\
9\end{array}$ & $\begin{array}{l}\text { Equine } \\
\text { digested }\end{array}$ & $\begin{array}{l}410 \\
320\end{array}$ & $\begin{array}{l}340 \\
340\end{array}$ & $\begin{array}{l}0.299 \\
0.268\end{array}$ & $\begin{array}{l}5.0 \\
6.0\end{array}$ & $\begin{array}{l}6.0 \\
4.5\end{array}$ \\
\hline $\begin{array}{l}10 \\
11 \\
12\end{array}$ & $\begin{array}{l}\text { Rabbit } \\
\text { digested }\end{array}$ & $\begin{array}{l}300 \\
340 \\
315\end{array}$ & $\begin{array}{l}80 \\
80 \\
70\end{array}$ & $\begin{array}{l}0.057 \\
0.027 \\
0.027\end{array}$ & $\begin{array}{l}0.075 \\
0.065 \\
0.13\end{array}$ & $\begin{array}{l}83.0 \\
45.1 \\
22.6\end{array}$ \\
\hline
\end{tabular}

* Avidity of antitoxin was taken into consideration.

with the neutralization index. Because, the neutralization index of the guinea pigs immunized with guinea pig antitoxic serum was more than 0.1 . If the toxin injected intracutaneously should be neutralized in the injected region $(0.2$ to $0.3 \mathrm{~g}$ of the skin), the concentration of tissue antitoxin should be 30 to $50 \%$ of the circulating antitoxin concentration. But, in order to clarify the relation between the titer of Q.S.T. and the tissue antitoxin concentration, it must be confirmed that the most tissue antitoxin was extracted by our procedure. $\mathrm{I}^{131}$ - 
labeled $\gamma$-globulin was used for this purpose. $\mathrm{I}^{131}$-labeled globulins of guinea pig, rabbit and horse serum and $\mathrm{I}^{131}$-labeled equine antitoxin digested were injected intravenously to guinea pigs. Twenty-four hours later, the specific activity of the serum and the skin were determined and the ratio between them was calculated in each case. Thereby, it was shown that the ratio was independent on the property of $\gamma$-globulin and that the concentration of $\gamma$-globulin in the

Table 6. Concentration of $\mathrm{I}^{131}-\gamma$-globulin in the skin

\begin{tabular}{|c|c|c|c|c|c|c|c|}
\hline \multirow[t]{2}{*}{ No. } & \multirow[t]{2}{*}{$\gamma$-globulin } & \multirow{2}{*}{$\begin{array}{c}\text { Body- } \\
\text { weight }\end{array}$} & \multirow{2}{*}{$\begin{array}{c}\text { Dosis of } \\
\text { injection } \\
\text { counts } / \mathrm{min} .\end{array}$} & \multicolumn{2}{|c|}{$\begin{array}{l}\text { Radioactivity } \\
\text { counts } / \mathrm{min} / \mathrm{g}\end{array}$} & \multirow{2}{*}{$\frac{\text { Skin }}{\text { Serum }}$} & \multirow{2}{*}{$\begin{array}{l}\text { Skin/Dosis of } \\
\text { injection per } \\
\text { body-weight }\end{array}$} \\
\hline & & & & Skin & serum & & \\
\hline & \multirow{4}{*}{ Guinea pig } & \multicolumn{4}{|c|}{$\times 10^{2}$} & \multicolumn{2}{|l|}{$\%$} \\
\hline \multirow{3}{*}{$\begin{array}{l}1 \\
2 \\
3\end{array}$} & & 335 & 8956 & 347 & 12590 & 2.8 & 13 \\
\hline & & 320 & 10622 & 813 & 15160 & 5.4 & 25 \\
\hline & & 345 & 10622 & 480 & 15460 & 3.1 & 16 \\
\hline \multirow{3}{*}{$\begin{array}{l}4 \\
5 \\
6\end{array}$} & \multirow{3}{*}{ Rabbit } & 390 & 10570 & 662 & 16410 & 4.0 & 24 \\
\hline & & 360 & 9870 & 454 & 15570 & 2.9 & 17 \\
\hline & & 360 & 9870 & 1087 & 16080 & 6.8 & 37 \\
\hline \multirow{3}{*}{$\begin{array}{l}7 \\
8 \\
9\end{array}$} & \multirow{3}{*}{ Equine } & 330 & 9650 & 659 & 19720 & 3.3 & 23 \\
\hline & & 330 & 9650 & 1042 & 21360 & 4.9 & 36 \\
\hline & & 325 & 8360 & 622 & 17400 & 3.6 & 24 \\
\hline \multirow{3}{*}{$\begin{array}{l}10 \\
11 \\
12\end{array}$} & \multirow{3}{*}{$\begin{array}{l}\text { Equine } \\
\text { digested }\end{array}$} & 285 & 3342 & 279 & 4750 & 5.9 & 24 \\
\hline & & 260 & 3342 & 266 & 5490 & 4.8 & 21 \\
\hline & & 295 & 3342 & 270 & 6000 & 4.5 & 24 \\
\hline
\end{tabular}

skin, was only $3-4 \%$ of that in the serum. This value is too small as compared with the neutralizing activity to the toxin injected intracutaneously though it was a little higher than the concentration of tissue antitoxin extracted (Table 6).

4. Disappearance Rate of Diphtheria Toxoid from the Injected Region.

From the above described findings, either the disappearance rate of toxoid injected intracutaneously or the concentration of antitoxin in the region following the injection of toxin should be different depending on the property of antitoxin used for immunization. Since otherwise, the difference of the neutralization index described above would not be explained. In this connection, diphtheria toxoid (Purity: $0.00057 \mathrm{mg} \mathrm{N} / \mathrm{Lf}$ ) labeled with $\mathrm{I}^{131}$ was injected intracutaneously to guinea pigs immunized and the disappearance rate of toxoid from the injected region was pursued. Namely, two groups of guinea pigs were immunized passively with 100 units of guinea pig antitoxin and 550 units of equine antitoxin respectively. After 24 hours, the circulating antitoxin titers were determined. Some of these groups were injected intracutaneously with toxin and the titer of Q.S.T. was determined. It was 0.1 to $0.2 \mathrm{LR}$ in all animals. Then, another guinea pigs of these groups received 4 intracutaneous injections, $0.1 \mathrm{cc}(0.3 \mathrm{Lf})$ of each, of the $\mathrm{I}^{131}$-labeled toxoid. After varying intervals, each region was removed in turn and its radioactivity was determined. The disappearance rate of toxoid was calculated from their radioactivity. As 
shown in Fig. 3, the disappearance rate of toxoid was independent on the property of antitoxin used. Even when the labeled toxoid was injected intracutaneously to normal guinea pigs, the disappearance rate of the toxoid was similar to the one observed in immunized guinea pigs.

In the next place, guinea pigs were immunized with three kinds of diphtheria toxoid (100 Lf of plain toxoid, $30 \mathrm{Lf}$ of alum-precipitated toxoid, $30 \mathrm{Lf}$ of toxoid mixed with Freund's adjuvant). After 4 weeks, their circulating antitoxin titers were determined to be 2 to 4 units per cc. Q.S.T. was carried out in some guinea pigs of the three groups. Its titer was 1 to 2 LR in every animal. Three Lf of labeled toxoid were injected intracutaneously to other immunized guinea pigs of each group and the disappearance rate of toxoid was determined. As shown in Fig. 4, the disappearance rate of toxoid was scarecely influenced by

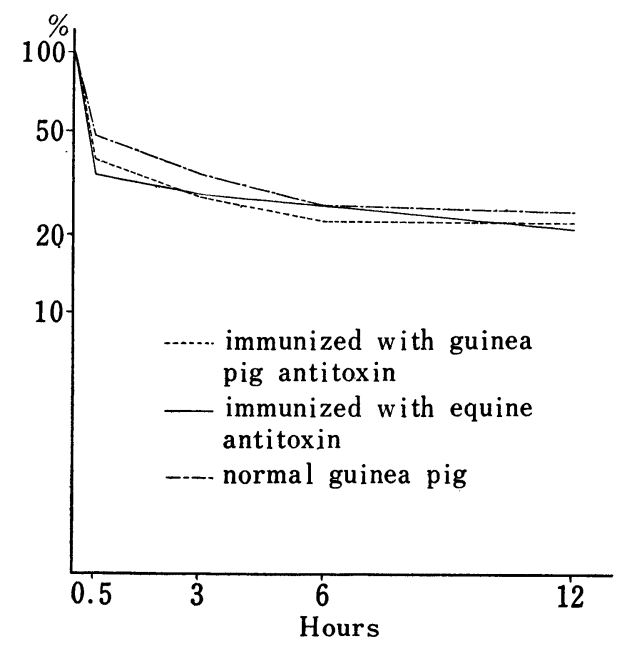

Fig. 3. Disappearance rate of toxoid from the region. I. passive immunization.

the immunization. This time, Arthus reaction was not observed in passively immunized guinea pigs, however, it was observed in actively immunized ones. From these findings, it may safely be said that the disappearance rate of antigen from the region is not influenced either by the property of antitoxin used for passive immunization or the degree of immunity.

\section{Accumulation of Antitoxin after the Injection of Toxin.}

In the next place, change of antitoxin concentration in the region after the injection of toxoid was pursued. In this experiment, guinea pigs were immunized with $\gamma$-globulin fraction of antitoxic sera labeled with $\mathrm{I}^{131}$. Twenty four hours later, these guinea pigs received 4 intracutaneous injections, 0.1 cc each, of purified toxoid. The dosage of toxoid injected was comparable to the titer of each animal. Each injected region, corresponding to the wheal by injection 
( 0.2 to $0.3 \mathrm{~g}$ ), was removed at varying intervals and its radioactivity was determined. The concentration of antitoxin in the region was estimated by the radioactivity. Namely, 24 hours after the injection of 32 units of guinea pig antitoxin, the circulating antitoxin titer and the titer of Q.S.T. were 0.60 to 0.66 units and 0.1 to $0.2 \mathrm{LR}$ respectively. Then, another guinea pigs which had been immunized with the same dosage of the antitoxin was injected intracutaneously with 0.2 Lf of toxoid and the antitoxin concentration in the region immediately before and after the injection was determined from its radioactivity. Antitoxin concentration in the region, 5 minutes after the toxoid injection, was 0.06 units which was much higher as compared with 0.0078 units in a control site. In other words, antitoxin concentration in the region increased immediately after the injection of toxoid by 7 to 8 times (Fig. 5). Thus, the disappearance curve of toxoid, shown in Fig. 3, was introduced into Fig. 5. The results obtained

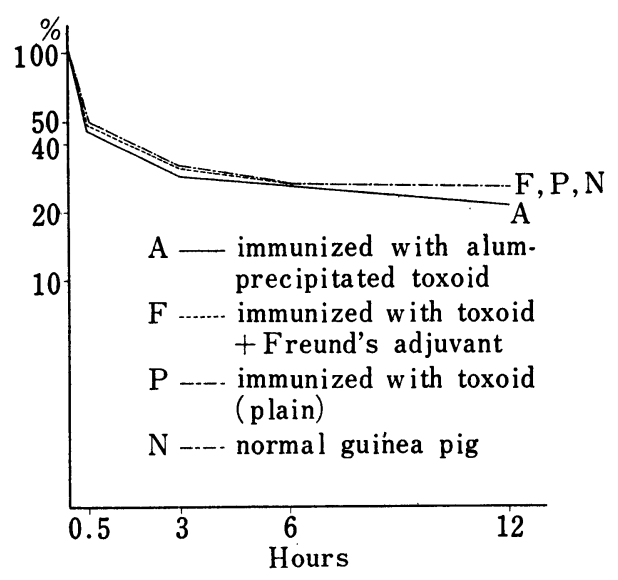

Fig. 4. Disappearance rate of toxoid from the region. II. active immunization.

proved that the antitoxin concentration was almost comparable to the concentration of toxin in the region, when the dosis of toxin injected was corresponding to the titer of Q.S.T. ( 0.1 to $0.2 \mathrm{Lf})$. On the other hand, guinea pigs were immunized with 80 units of equine antitoxin labeled with $\mathrm{I}^{131}$. Twenty four hours later, the titer of Q.S.T. was determined to be 0.05 to $0.08 \mathrm{LR}$. Then, $0.15 \mathrm{Lf}$ of toxoid was injected intracutaneously to the guinea pigs immunized passively with the same dosis of labeled equine antitoxin and the concentration of antitoxin in the region was pursued. In this case, however, the concentration of antitoxin in the region scarecely increased by the injection of toxoid. By the way, the concentration of antitoxin immediately before the toxin injection $(0.003$ to 0.0035 units) was almost comparable to the concentration of toxin in the region after its injection (Fig. 6). 


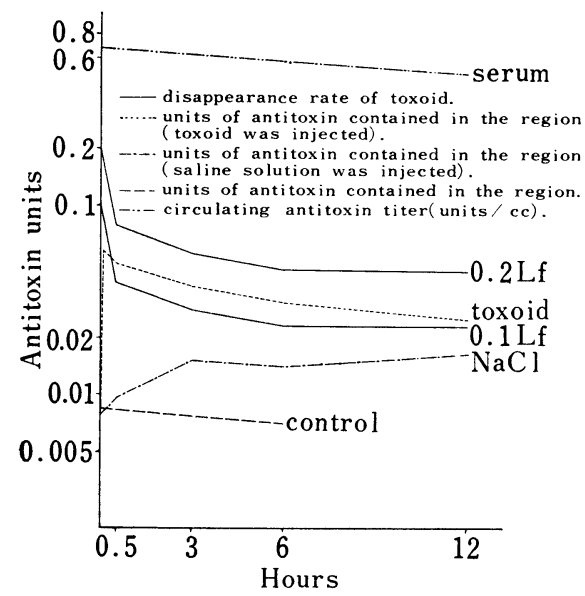

Fig. 5. Tissue antitoxin and its relation to the schick level. i) passive immunization with guinea pig antitoxin.

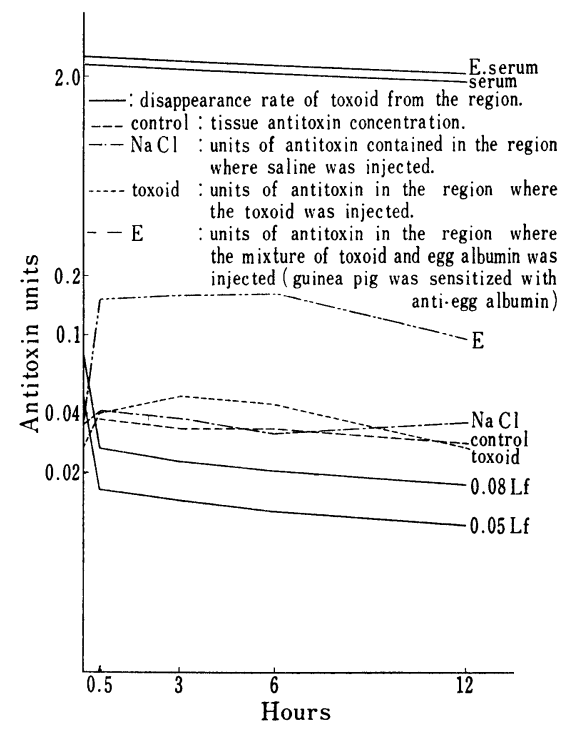

Fig. 6. Change of tissue antitoxin concentration and its relation to schick level. ii) passive immunization with equine antitoxin. 
Thirdly, guinea pigs were actively immunized with alum-precipitated toxoid. Four weeks later, these guinea pigs were injected intravenously with guinea pig antitoxin labeled with $\mathrm{I}^{131}$. Twenty four hours later, circulating antitoxin titer was determined to be 3 units/cc. 0.1 cc of toxoid ( $2 \mathrm{Lf}$ ), of which dosis is comparable to the titer of Q.S.T. (2 LR), was injected intracutaneously. The antitoxin concentration in the region was estimated from the radioactivity. As shown in Fig. 7, the increase of antitoxin concentration in the region was

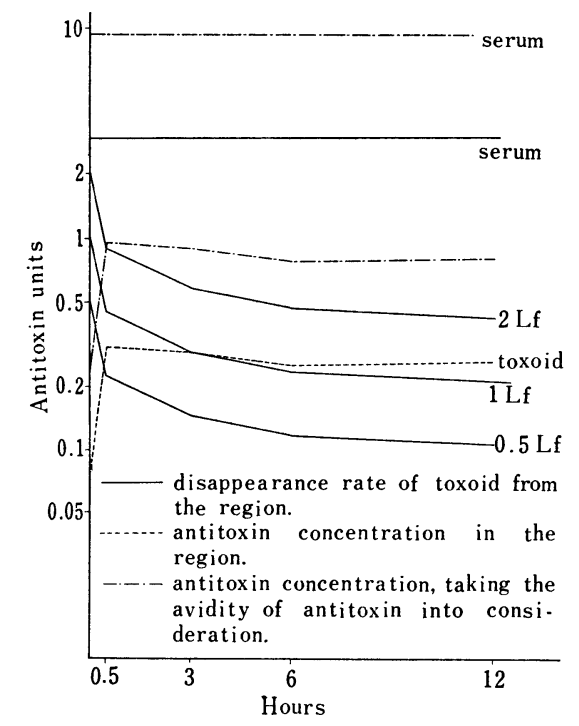

Fig. 7. Change of tissue antitoxin concentration and its relation to schick level. iii) active immunization.

observed immediately after the injection of toxoid. Moreover, the tissue antitoxin was kept at a higher level for a long time as compared with the one observed in passively immunized guinea pigs. In this case, however, units of antitoxin in the region, 30 minutes after the toxoid injection, was about 0.3 units and much less than the concentration of toxoid in the region. Because the concentration of toxoid in the region, 30 minutes after the injection, was assumed to be 0.45 to $0.9 \mathrm{Lf}$, when 1 to $2 \mathrm{Lf}$ of toxoid was injected. By the way, the avidity of antitoxin of actively immunized guinea pigs was not so high as compared with that of antitoxin used for passive immunization. Therefore, in order to estimate the antitoxin concentration in the region as well as in the serum of these actively immunized guinea pigs, avidity of antitoxin should be taken. into consideration. Thus, $K_{1}$ of circulating antitoxin of the guinea pigs was determined and the concentration of the tissue antitoxin as well as circulating antitoxin were calculated taking the avidity of antitoxin into consideration. (Jerne, 1951). The concentration of tissue antitoxin and the circulating anti- 
toxin immediately before the injection of toxoid were $0.25 \mathrm{u} / \mathrm{cc}$ and $1.9 \mathrm{u} / \mathrm{cc}$ respectively. The concentration of tissue antitoxin in the region 30 minutes after the injection of toxoid became nearly 1 unit. Accordingly, it was confirmed that the neutralizing activity to the toxin injected intracutaneously can be explained by the dosis of antitoxin in the region immediately after the toxin injection.

In short, the accumulation of antitoxin in the region after the toxin injection was observed in actively immunized guinea pigs as well as passively immunized ones with guinea pig antitoxin. On the other hand, when equine antitoxin was used for passive immunization, such accumulation of antitoxin was not observed. In each case, the titer of Q.S.T. could be explained by the dosis of antitoxin in the region immediately after the toxin injection. Accordingly, the difference of neutralization index depending on the property of antitoxin used for immunization would be due to the accumulation of antitoxin in the region.

As described above, guinea pig antitoxin has sensitizing activity, while equine antitoxin has no sensitizing activity. The accumulation of antitoxin is assumed to be due to the allergic reaction. Because, it is well known that the increase of capillary permeability is caused by allergic reaction. In this connection the influence of allergic reaction on the accumulation of antitoxin into the region was studied. As a basic experiment, guinea pigs were injected intravenously with $1 \mathrm{cc}$ of anti-egg albumin rabbit serum and 24 hours later serial dilution of egg albumin, $0.1 \mathrm{cc}$ each, were injected intracutaneously. As the result of this, it was observed that $1 \mathrm{mg}$ of egg albumin was required to cause Arthus reaction. Then, guinea pigs were injected intravenously with 80 units of labeled equine antitoxin and $1 \mathrm{cc}$ of the anti-egg albumin serum. Twenty four hours later, four intracutaneous injections, $0.1 \mathrm{cc}$ of each mixture containing $0.15 \mathrm{Lf}$ toxoid and $0.01 \mathrm{mg}$ of egg albumin, were made. As shown in Fig. 6, radioactivity of the region increased by about 4 times 30 minutes after the injection. In other words, the accumulation of antitoxin into the region was observed even when equine antitoxin was used for immunization, provided that slight allergic reaction occurs by other antigen antibody system.

6. Significance of Allergic Reaction on the Neutralization of Toxin Injected Intracutaneously.

As the result of the above experiments, it was assumed that the increase of capillary-permeability due to allergic reaction plays very important role in the neutralization of toxin injected intracutaneously. In this connection, relation between the intensity of permeability and the neutralization index was studied. Namely, guinea pigs were immunized passively with guinea pig antitoxin or equine antitoxin and 24 hours later, $1.5 \mathrm{cc}$ of $0.5 \%$ Evans Blue per $\mathrm{kg}$ body weight was injected intravenously. Immediately after, serial dilutions of toxin were injected intracutaneously and Q.S.T. was carried out. When capillary per- 
meability increased, the injected region began to colour within 2 to 3 minutes. The sensitivity of capillary permeability was determined by the colour of injected region 30 minutes after the toxin injection (Benacerraf et al., 1954). The titer of Q.S.T. was determined 40 hours after the injection. The results were shown in Table 7. Namely, when guinia pig antitoxin was used for immuniza-

Table 7. Relation between the increase of permeability and neutralization index

\begin{tabular}{ccccc}
\hline Antitoxin & $\begin{array}{c}\text { Units used for } \\
\text { immunization } \\
/ 100 \mathrm{~g}\end{array}$ & $\begin{array}{c}\text { Circulating } \\
\text { antitoxin } \\
\text { units/cc }\end{array}$ & $\begin{array}{c}\text { Increase of } \\
\text { permeability }\end{array}$ & $\begin{array}{c}\text { Neutralization } \\
\text { index }\end{array}$ \\
\hline Guinea pig & 13 & $0.65 \sim 1.0$ & + & $0.1 \sim 0.13$ \\
Guinea pig & 1.7 & $0.15 \sim 0.2$ & + & $0.03 \sim 0.055$ \\
Equine & 13 & $0.8 \sim 1.0$ & - & $0.012 \sim 0.02$ \\
Equine+Anti Ea & 11 & $0.7 \sim 1.3$ & H $^{*}$ & $0.11 \sim 0.2$ \\
\hline
\end{tabular}

* toxin injected contained $0.02 \%$ egg albumin

tion, increase of capillary permeability was always observed and the neutralization index was high even when 1.5 units of antitoxin was used. On the other hand, when equine antitoxin was used, increase of permeability was not observed and the neutralization index was lowest. By the way, when guinea pigs were immunized with equine antitoxin mixed with anti-egg albumin and the mixture of $0.01 \mathrm{mg}$ of egg albumin and serial dilution of test toxin were injected intracutaneously, increase of capillary permeability was observed and the neutralization index was very high. In general, the neutralization index parallels with the intensity of capillary permeability. Therefore, it seems that the allergic reaction plays an important role in the neutralization of toxin injected intracutaneously.

\section{DisCUSSION}

It has hitherto been believed that antitoxic immunity is established by sufficient circulating antitoxin. In fact, the combination of toxin with antitoxin in the circulation was demonstrated experimentally (Ishizaka, 1952) and the intensity of antitoxic immunity against toxin intravenously or subcutaneously inoculated was explained by the dosis of antitoxin in the circulation (Kurokawa et al., 1954). On the contrary, the tolerance of actively immunized guinea pigs to the toxin injected intracutaneously did not parallel with the titer of the circulating antitoxin, but with the concentration of tissue antitoxin (Nakano, 1954; Ishizaka et al., 1955). Accordingly, it was assumed that the tissue antitoxin plays an important role in the neutralization of toxin intracutaneously injected. In this connection, the mechanism of toxin neutralization in the tissues was studied in the present report.

For this purpose, guinea pigs were passively immunized with several kinds of antitoxin and the quantitative Schick test was carried out. From the result, it was proved that the neutralization index was different depending on the 
property of antitoxin used for passive immunization. Namely, when the guinea pigs were immunized with antitoxin which has sensitizing activity-guinea pig antitoxin and rabbit antitoxin-, the neutralization index was very high, while the neutralization index was low, when they were immunized with equine antitoxin which has no sensitizing activity. Thus, it was examined whether or not the ratio of the tissue antitoxin concentration to the circulating antitoxin concentration would be different depending on the property of antitoxin, however, it was not the case. This finding is in accordance with the result obtained previously. As the ratio of the concentration of antitoxin in the intestinal tissue to the concentration of the circulating antitoxin was irrespective of the species of antitoxin used for passive sensitization (Ishizaka et al., 1957). Therefore, the tolerance to the toxin injected intracutaneously is determined not only by the concentration of tissue antitoxin but also by the property of antitoxin in the tissues. By the way, it was demonstrated that the concentration of antitoxin in the skin is very small as compared with the neutralizing activity, especialy when the guinea pig antitoxin was used. Namely, 24 hours after the

Table 8. Toxin-antitoxin reactions in guinea pigs passively immunized

\begin{tabular}{|c|c|c|c|c|c|c|c|}
\hline \multirow{3}{*}{$\begin{array}{l}\text { Kind of } \\
\text { antiserum } \\
\text { used for } \\
\text { immunization }\end{array}$} & \multicolumn{2}{|c|}{ Quantitative Schick test } & \multicolumn{5}{|c|}{ Allergic reactions } \\
\hline & \multirow{2}{*}{$\begin{array}{l}\text { Neutral- } \\
\text { ization } \\
\text { Index }\end{array}$} & \multirow{2}{*}{$\begin{array}{c}\text { Titer of Q.S.T. } \\
\text { Units of } \\
\text { antitoxin } \\
\text { used for } \\
\text { immunization }\end{array}$} & \multicolumn{2}{|c|}{ Anaphylaxis } & \multirow{2}{*}{ Arthus } & \multicolumn{2}{|c|}{ Prausnitz-Küstner } \\
\hline & & & Shock & Intestine & & $30 \mathrm{~min}$ & $18 \mathrm{~h}$ \\
\hline Guinea pig & 0.135 & 1.31 & + & + & + & + & + \\
\hline Rabbit & 0.12 & 1.05 & + & + & + & + & + \\
\hline $\begin{array}{c}\text { Rabbit } \\
\text { digested }\end{array}$ & 0.118 & 0.035 & \pm & - & - & + & - \\
\hline Horse & 0.025 & 0.20 & - & - & - & - & - \\
\hline $\begin{array}{l}\text { Horse } \\
\text { digested }\end{array}$ & 0.0205 & 0.19 & - & - & - & - & - \\
\hline
\end{tabular}

passive immunization with guinea pigs antitoxin, the dosis of antitoxin contained in $0.1 \mathrm{~g}$ of the skin was only about $5 \%$ of the titer of Q.S.T. As the weight of the skin corresponding to the injection-whealing was 0.2 to $0.3 \mathrm{~g}$, the dosis of antitoxin in the region would be equivalent to 10 to $15 \%$ of the toxin which can be neutralized. On the other hand, when the guinea pigs were immunized with equine antitoxin, the dosis of antitoxin in the region was 50 to $75 \%$ of the titer of Q.S.T. In other words, the tolerance to the toxin injected intracutaneously can never be explained by the dosis of antitoxin contained in the injected region when the guinea pig antitoxin was used for immunization.

In this connection, what is interesting is the palalelism between the neutralization index and the sensitizing activity of antitoxin (Table 8). From this finding, it is conceivable that the allergic reaction has some connection with the high neutralization index. Korugold et al. (1953) reported that the disappearance rate of the antigen is rapid, when Arthus reaction occurs. Then, the disappearance rate of toxin from the region was pursued in two cases in 
which the guinea pig antitoxin and the equine antitoxin were used for immunization. In the present experiment, however, the rate of disappearance was not influenced by the species of antitoxin nor the presence of antitoxin in the tissues in the case of passive immunization. But the Arthus reaction was not observed in these cases. Even in actively immunized ones, in which the neutralization index was very high and the allergic reaction was observed, the disappearance rate of toxoid was comparable with that observed in normal guinea pigs. Such divergence of the data would be due to the intensity of allergic reaction. Because, the allergic reaction observed in our experiment was not so severe as compared with the one observed by Korngold et al. (1953). Then, the concentration of tissue antitoxin was pursued after the injection of toxoid. Whereas, it was proved that the tissue antitoxin increased immediately after the injection of toxoid provided that the guinea pigs were immunized actively or passively with guinea pig antitoxin. On the contrary, when the guinea pigs were immunized with equine antitoxin, the increase of tissue antitoxin in the region never occurred. In other words, the increase of tissue antitoxin occurs only when the antitoxin having sensitizing activity was used for immunization. It is well known that the increase of the capillary permeability is caused by allergic reaction. Therefore, it is conceivable that the accumulation of antitoxin in the region would be the result of the increase of a capillary permeability. The increase of permeability was observed in guinea pigs which had been immunized with only 1.4 units $/ 100 \mathrm{~g}$ body weight of guinea pig antitoxin.

The increase of capillary permeability paralleled with the neutralization index. Moreover, when the capillary permeability was increased by the allergic reaction, caused by egg albumin anti-egg albumin system, the neutralization index of passively immunized guinea pig with equine antitoxin became high. From these findings, it is likely that the antitoxin, which flowed into the tissues by allergic reaction, plays an important role in the neutralization of toxin in the tissues. It has been proved that much antitoxin is required to neutralize the toxin in the susceptible tissues. In this experiment, however, the increase of capillary permeability would be so rapid that the antitoxin from the circulation would be in time to neutralize the toxin before it combines with the tissues.

Friedeman (1947) observed that the effect of antitoxin was strongly enhanced in Schick test of passively immunized rabbit, when the toxin was dissolved in the solution of certain substances other than saline. For example, histamine as well as nutrient broth has such effect. According to Friedeman, these results were explained by the increase of the capillary permeability to antitoxin with these substances. Such a state of affairs would be the case in our experiment. Namely, the high neutralization index would be explained by the increase of capillary permeability due to allergic reaction in the region. In short, the significance of tissue antitoxin in Schick test would be as follows. The tissue antitoxin would neutralize a part of toxin injected. At the same time, 
the toxin antitoxin reaction in the tissues causes the allergic reaction and the capillary permeability increases. Thus a considerable dosis of antitoxin flowed into the tissues and large dosis of toxin would be neutralized in the tissues.

\section{SUMMARY}

1. The ratio of the titer of quantitative Schick test to the circulating antitoxin titer (Neutralization Index) is different depending on the period after passive immunization and the property of antitoxin used.

2. When the antitoxin having a sensitizing activity was used for passive immunization, the neutralization index was high. In this case, the titer of quantitative Schick test was never explained by the concentration of tissue antitoxin immediately before the injection of toxin. But the neutralization index was low when the equine antitoxin, lacking the sensitizing activity, was used for immunization.

3. The disappearance rate of toxin or toxoid from the injected region was independent either on the property of antitoxin or the degree of immunization.

4. The capillary permeability in the skin increases immediately after the intracutaneous injection of the toxin when the guinea pigs had been passively immunized with guinea pig antitoxin or actively immunized.

5. The neutralization index parallels with the increase of capillary permeability.

6. From these findings, the role of tissue antitoxin in Schick test was discussed. It was assumed that the tissue antitoxin neutralizes a part of toxin injected. As the result of allergic reaction the capillary permeability increases. The circulating antitoxin flows into the tissues and plays an important role in the neutralization in the tissues.

We should like to express our hearty gratitude for the cordial guidance of Dr. Keizo Nakamura of the National Institute of Health, Tokyo.

\section{REFERENCES}

Benacerraf, B., Biozzo, G. and Halpern, B. N. (1954): The effect of histamine upon the local fixation of antibodies in the skin of the guinea pig. J. Immunol., 73, 318-321.

Cohen, S. (1951): Determination of antibody through the use of $\mathrm{I}^{131}$ label: Experiments with equine diphtherial antitoxin. J. Immunol., 67, 339-346.

Deutsch, H. F. and Nichol, J. C. (1948): Biophysical studies of blood plasma proteins. XI Fractionation studies of normal and immune horse serum. J. Biol. Chem., $176,797-812$.

Friedemann, U. (1947): Dynamics and mechanism of immunity reactions in vivo. Bact. Rev., 11, 275-302.

Ishizaka, K. (1952): Studies on the toxin anaphylaxis. III. Inhibition of toxin anaphylaxis caused by antitoxin in the blood. Jap. J. Bact., 7, 167-172. (text in Japanese) .

Ishizaka, K. and Ishizaka, T. (1953): Studies on the toxin anaphylaxis and the rate of combination of diphtheria toxin and antitoxin in vitro. Jap. J. M. Sc. \& Biol., 6, 131-142. 
Ishizaka, K., Ishizaka, T. and Sugahara, T. (1955): Studies on the relationship between toxin anaphylaxis and antitoxic immunity. II. Significance of the relation between the tissue antitoxn and circulating antitoxin in the toxin anaphylaxis and antitoxic immunity. Jap. J. M. Sc. \& Biol., 8, 283-293.

Ishizaka, K., Ishizaka, T. and Sugahara, T. (1957): Quantitative studies on anaphylaxis in vitro. II. Studies on the species difference of diphtheria antitoxin in the sensitizing activity. Jap. J. M. Sc. \& Biol., 10, 93-103.

Ishizaka, T. (1955): Studies on the complement fixation reaction of diphtherial toxin and antitoxin. III. Influence of denaturation of antitoxin on the complement fixing activity. Jap. J. Bact., 10, 211-217 (text in Japanese).

Jensen, C. (1933): Die intrakutane Kaniechen Methode zur Anwendung von Diphtherie toxin und Diphtherie-antitoxin. Acta path. et Microbiol. scandinav., suppl., 14.

Jerne, N. K. (1951) : A study of avidity. Acta path. et microbiol., scandinav., suppl., 87.

Korngold, L., Stahley, G. L., Dodd, M. C. and Myers, W. G. (1953) : The comparative retention of antigen in the skin of immune and normal rabbit as determined with egg albumin labeled with radioactive iodine. J. Immunol., 70, 345-351.

Kuhns, W. J. and Pappenheimer, A. M. (1952): Immunological studies of antitoxin produced in normal and allergic individuals hyperimmunized with diphtheria toxoid. II. A comparison between the immunological properties of precipitating and non-precipitating (skin sensitizing) antitoxins. J. Exper. Med., 95, 375-392.

Kurokawa, M., Murata, R., Nakano, T., Yamada, T. and Kubota, K. (1951) : Studies on the antitoxic immunity of diphtheria. I. The relationship between circulating antitoxin titer of actively immunized guinea pigs and their tolerance to toxin intracutaneously injected. Jap. M. J., 4, 369-378.

Kurokawa, M., Nakano, T., Takao, M. and Kondo, T. (1954): Studies on the antitoxic immunity to diphtheria. II. Antitoxic immunity against toxin intravenously or subcutaneously inoculated. Jap. J. M. Sc. \& Biol., 7, 295-300.

Nakano, T. (1954): Studies on the antitoxic immunity of diphtheria, especially on the immunity against the toxin inoculated intracutaneously. II. Antitoxin concentration in skin tissues. Jap. J. Bact., 9, 203-207 (text in Japanese).

Nichol, C. and Deutsch, H. F. (1948): Biophysical studies of blood plasma proteins VII. Separation of $\gamma$ globulin from the sera of various animals. J. Am. Chem. Soc., 70, 80-83.

Pope, C. G. (1939): The action of proteolytic enzymes on the antitoxins and proteins in immune sera. II. Heat denaturation after partial enzyme action. Brit. J. Exper. Path., 20, 201-212.

Pressman, D. and Keighley, G. (1948): The zone of activity of antibodies as determined by the use of radioactive tracers. J. Immunol., 59, 141-146.

Talmage, D. W., Dixon, F. J., Bukantz, S. C. and Damin, G. J. (1951) : Antigen elimination from the blood as an early manifestation of the immune response. $J$. Immunol., $67,243-255$. 